Original scientific paper

\title{
METHODOLOGY FOR SELECTION OF THE VARIANT FOR OPENING THE DEEPER PARTS OF THE TORANICA MINE
}

\author{
Zoran Despodov $^{1}$, Nikolinka Doneva ${ }^{1}$, Stojanče Mijalkovski ${ }^{1}$, Marija Hadži- \\ Nikolova ${ }^{1}$
}

Received: May 21, 2021

Accepted: June 11, 2021

\begin{abstract}
Opening an underground mine or part of it presents complex and responsible issue, which affects the economy and effectiveness of the mine operation. This paper presents a methodology for selecting the optimal variant for opening, the lead-zinc ore mine Toranica, Macedonia. Six variants of opening and haulage of ore and waste rocks in the deeper parts of the ore deposit have been considered. After the performed analysis, the optimal variant for opening and haulage for the Toranica mine was determined.
\end{abstract}

Keywords: drift, central ore pass, decline, haulage, ore

\section{INTRODUCTION}

Opening and development of the ore deposits during underground mining is a problem of strategic character for a mining enterprise, both in the period of mine construction and of its development. This significance stems from the huge financial investments in the construction of capital underground mining facilities, the number of employees engaged and the time required for their development (Despodov and Mijalkovski, 2015; Savić et al., 2011). Mine opening as a phase in the technological process of underground mining, enables its connection with the surface with development of different types of underground facilities. The opening premises are used for haulage and hoisting of ore, delivery of material, workers transportation, ventilation, drainage, and supply of the mine with energy (Jovanović, 1990; Gluščević, 1974).

The mine opening can be done with: adit, shaft, sloping facilities or a combination. These facilities often are made in the foot wall of the ore body, but they can also be made in the hanging wall, as well as in the ore body itself. The selection of opening method of the ore deposit is influenced by several factors: the configuration of the terrain above the

\footnotetext{
${ }^{1}$ Faculty of natural and technical sciences, Goce Delčev, Štip, N. Macedonia E-mails: zoran.despodov@ugd.edu.mk; nikolinka.doneva@ugd.edu.mk; stojance.mijalkovski@ugd.edu.mk; marija.hadzi-nikolova@ugd.edu.mk;
} 
deposit and the environment, the position and shape of the ore body and its relationship with the surface, the depth of mining, the determined reserves and the forecast for the future, ground tectonics, physical - mechanical properties of ore and surrounding rocks, the presence of water, etc. (Doneva, 2014).

\section{METHODOLOGY FOR SELECTION OF VARIANT FOR OPENING THE UNDERGROUND MINE}

There are several approaches that can be applied to determine the optimal variant for opening and ore haulage of underground mine. This paper presents a simple method based on the analysis of the ratio of qualitative indicators to the possible variants of opening, which often is used in preliminary studies.

The ratio between the following parameters can be used in engineering practice, as possible way to make a decision for choosing the most favorable variant:

1. $\mathrm{L}$ - length of required underground mine facilities;

2. Q - annual mine capacity;

3. $\mathrm{T}$ - life cycle of mine;

4. Costs for construction of the necessary underground facilities;

5. Costs for maintenance of facilities during operation;

6. Haulage and hoisting costs;

7. Ventilation costs etc.

All these costs and investments should be shown for each input parameter in analysis and reduced to a meter owed by the facility. Then for each opening variant, these costs have been summarized and graphically shown. By analyzing the obtained data, we can find out which of the analyzed variants requires the lowest costs.

In order to avoid complicating the analysis with a lot of data, which at some in the initial stage are not fully specified, the process is simplified by indexing the basic parameters, on the basis of which the analysis of the economic suitability of the variants for opening will be performed. The total costs for the analyzed variant (reduced to $1000 \mathrm{t}$ of produced ore and for the whole life cycle of ore deposit) can be presented in the form of a function:

$F=f(a, b, c, d, \ldots)$

where:

a - costs for construction of the necessary underground facilities; 
b - costs for maintenance of facilities during operation;

c - haulage and hoisting costs;

$\mathrm{d}$ - ventilation costs etc.

This function expressed by indexes can be written in the following form:

$F=f\left(I_{1}, I_{2}, I_{3}, \ldots . ., I n\right)$

where:

$\mathrm{I}_{1}, \mathrm{I}_{2}, \mathrm{I}_{3}, \ldots \ldots, \mathrm{I}_{\mathrm{n}}$ - indexes of the same parameters in different opening variants.

The integral form of the law that defines the costs, which influence the choice of the most favorable variant, can be presented as follows:

$F=F_{1}+F_{2}+F_{3}+\ldots \ldots+F_{n}$

where:

$F_{1}, F_{2}, F_{3}, \ldots \ldots, F_{n}-$ integral functions related to the dependence of the same parameters (construction, maintenance, hoisting, ventilation, etc.).

Determining the minimum of this function defines which of the proposed variants is closest to that minimum (Jovanović, Trajković and Tomašević, 1993).

For example, with expression of costs for the construction of these facilities through the ratio related to the cost for the construction of: drift, decline and shaft, where the lowest costs are indexed as 1 , then, if we do not conditionally claim the accuracy in this analysis of relations, it is possible to adopt the following indexing:

$\mathrm{I}_{\mathrm{dr}}=1 ; \mathrm{I}_{\mathrm{d}}=3$ and $\mathrm{I}_{\mathrm{sh}}=8$.

where are:

$\mathrm{I}_{\mathrm{dr}}-$ index for drift construction costs;

$I_{d}-$ index for decline construction costs;

$\mathrm{I}_{\mathrm{sh}}$ - index for shaft construction costs.

In that case the weighted cost value can be represented by a coefficient $K$, for every 1000 $\mathrm{t}$ of ore produced and life cycle of ore deposit - $\mathrm{T}$ [years]. This coefficient can be calculated as follows:

$K=\frac{I_{d r} \cdot L_{d r}+I_{d} \cdot L_{d}+I_{r} \cdot L_{r}+I_{o p} \cdot L_{o p}+I_{e d r} \cdot L_{e d r}}{Q^{-3} \cdot T}$

where are:

$\mathrm{I}_{\mathrm{dr}}-$ index for drift construction costs; 
$\mathrm{L}_{\mathrm{dr}}-$ drift length;

$\mathrm{I}_{\mathrm{dr}}-$ index for decline construction costs;

$\mathrm{L}_{\mathrm{d}}$ - decline length;

$\mathrm{I}_{\mathrm{r}}$ - index for ramp construction costs;

$\mathrm{L}_{\mathrm{r}}-$ ramp length;

$\mathrm{I}_{\mathrm{op}}-$ index for ore pass construction costs;

$\mathrm{L}_{\mathrm{op}}-$ ore pass length;

$\mathrm{I}_{\mathrm{edr}}$ - index for expanded drift construction costs;

$\mathrm{L}_{\text {edr }}-$ expanded drift length.

The costs of maintenance, haulage, and ventilation in each variant can be calculated in the same manner. The variant that has the minimum total cost is in fact the most favorable or the most rational variant for opening the underground ore deposit.

\section{BASIC DATA FOR THE TORANICA MINE}

\subsection{Location and short history of the Toranica mine}

The lead and zinc mine Toranica is located in the northeastern part of the Republic of North Macedonia, on the slopes of Mount Osogovo, near the Macedonian-Bulgarian border. It is $18 \mathrm{~km}$ away from Kriva Palanka, and $120 \mathrm{~km}$ from Skopje. The mine is located at a distance of $6 \mathrm{~km}$ from the international road Skopje - Kriva PalankaBulgarian border.

The beginnings of the geological research in Toranica dated from 1954, when the exploration of lead and zinc in the Osogovo ore region began. Due to poor results, exploration in the Toranica ore field in 1958 was stoped. Re-exploration of the Toranica ore body was carried out in 1974. The results of these research are positive, so that in 1976 the Mine for lead and zinc-Toranica was established, and a detailed research of quantitative and qualitative proof of the ore reserves was started. The construction of the Toranica Mine lasted from 1982 to 1987.

The Toranica mine started active production in 1987, with an annual production of 41,232 tons. Over the years its production has steadily increased so that in 1990 , it reached 314,210 tons of ore. The Toranica mine was constantly exploited, with two breaks, the first of which occurred due to the transformation of the ownership from public to private and lasted 5 years, and the second ones due to the change of the concessionaire for a period of 1 year. In April 2016, the company Bulmak 2016 DOOEL - Probistip, which still manages this mine, received a concession for exploitation of the Toranica mine.

\subsection{Geological characteristics of the Toranica ore deposit}

The Toranica deposit is located in the northern parts of the Sasa-Toranica ore region, within the metallogenetic zone Besna Kobila - Osogovo - Thassos. According to the 
surface manifestation of magmatism and mineralization, this ore field covers an area of about $30 \mathrm{~km}^{2}$.

Rocks from the metamorphic complex and tertiary volcanoes participate in the geological construction of the Toranica site and its immediate surroundings. The most common representatives of metamorphic rocks are gneisses and quartz graphite shales. The series of quartz-graphite shales has a special significance in the Toranica deposit, because it houses most of the lead and zinc ores. Spatially, these rocks lie between the roof and bottom gneisses and contain interstratified layers and lenses of cipolines and cipoline shales, as well as quartz lenses of various sizes. Tertiary volcanites are intruded into the metamorphic complex mostly in the form of dykes and forces. They have consistency after stretching up to several hundred meters and are parallel to the formation of shales and gneisses. Characteristic representatives of tertiary volcanoes are: quartz latites, dacites and andesite dacites.

Based on the research data, several types of ore bodies have been identified, as follows:

a) According to the connection for individual lithological members:

- ore bodies in quartz graphite shale,

- ore bodies in roof gneisses,

- ore bodies in volcanic rocks.

b) According to the shape of the ore bodies:

- layered ore bodies,

- layered-lens ores,

- rigid-impregnated ore bodies.

Based on the ore microscopic research and microsonnaise examinations in the Toranica deposit, ore minerals have been determined according to the stages and phases of the mining. The main minerals in the ore deposit are: galena, sphalerite, pyrite, chalcopyrite, pyrotine and others. Elaborate for recategorization of the ore reserves is in progress, which should confirm the geological ore reserves under level I $(\mathrm{k} .1408 .55 \mathrm{~m})$, ie the deeper parts of the ore deposit.

\subsection{Opening and development of the Toranica ore deposit for underground mining}

The underground mining field Toranica is spatially located at an altitude of 1250 to 1815 $\mathrm{m}$ with a northwest-southeast direction extending. To the southeast, the Toranica deposit borders with Sasa ore deposit. The extinction ore deposit has been explored at a distance of $1500 \mathrm{~m}$, and the thickness of the ore zone is about $100 \mathrm{~m}$. The Toranica ore deposit is 
open with: main haulage adit, main service ramp, two central ore passes and several adits, Fig.1. Access to the ore bodies is through the adits: I, II, IIa, III, IIIa, VI, VIa, IV, IVa and V. The I, IIa, IIIa adits presents haulage levels, while the II, III, IV, VI and V adits serve for development of the site vertically, i.e. they serve for drainage, ventilation and service. Longitudial section of the Toranica mine is displayed on Figure 1.

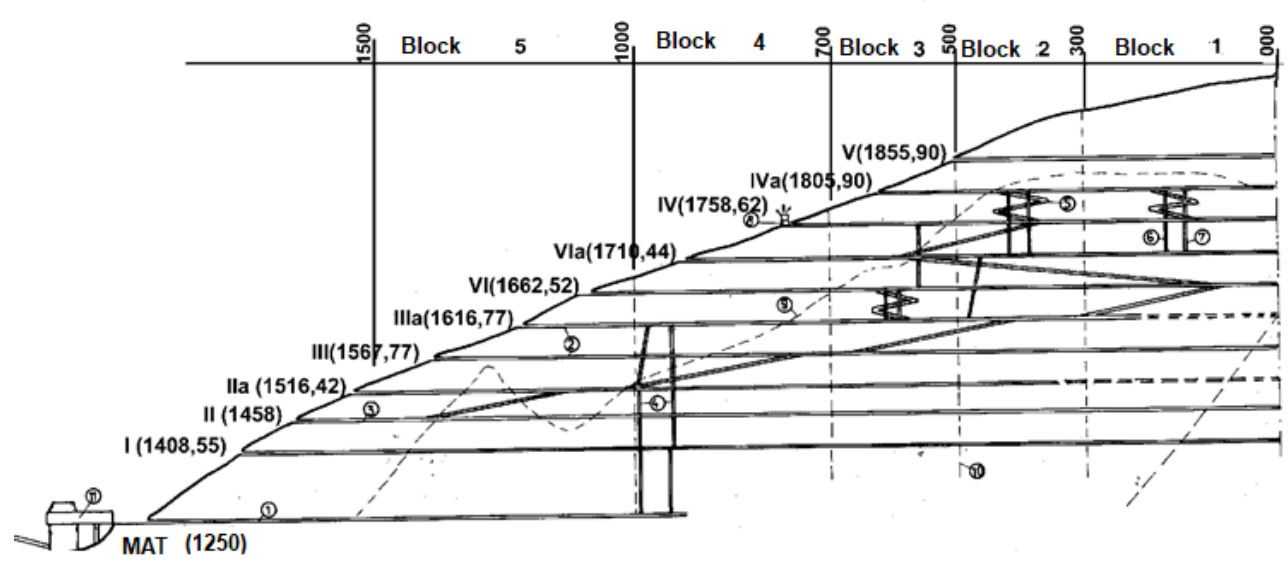

Figure 1 Longitudinal section of the Toranica mine: 1. Main adit transportation, 2. Levels, 3. Main service ramp, 4. Central ore pass, 5. Block ramp, 6. Ore pass, 7. Waste pass, 8. Fan station, 9. Limits of mineralization, 10. Limits of block, 11. Ore bin

\section{PROPOSED VARIANTS FOR OPENING AND HAULAGE FROM THE DEEPER PARTS OF TORANIVA MINE}

\subsection{Opening with existing underground infrastracture}

In this variant usage of part of the existing underground infrastructure of the Toranica Mine is proposed. This means that the existing MAT (Main adit transportation) will be used for rail transport of ore from the pit to the receiving flotation hopper. Additionally, in the footwall rocks will be made: sublevel Ia, two ore passes and two ventilation raises, as well as two block ramps, as showed on figure 2. The ore from the stopes to the ore passes will be haulaged by diesel trucks. 


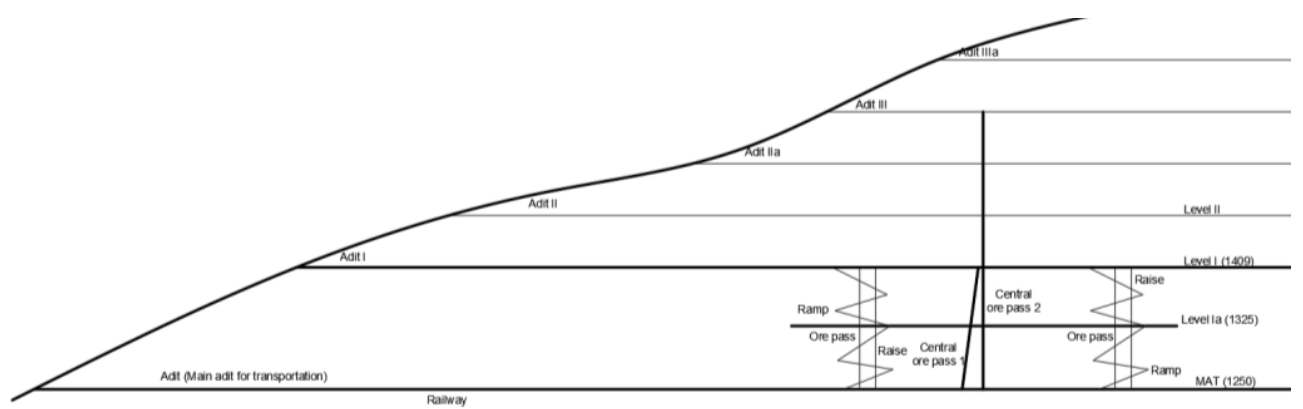

Figure 2 First variant of opening the Toranica ore deposit under level I using the existing underground infrastructure for haulage and ore export

4.2 Opening of production level I-Ia with Main haulage decline, and from production level Ia-MAT with the exissting underground facilities for ore haulage

In this variant, construction of Main haulage decline is proposed, with a slope of $12 \%$ to level Ia, a capital drift of level Ia, two central ore passes, two ventilation raises, as well as two block ramps from level I to MAT. The ore from the level I - Ia will be haulaged by mine trucks through the Main haulage decline to the surface, and further to the Flotation Bunker. While the ore produced by level Ia - MAT will be haulaged by railway through MAT to the Flotation bunker. This variant is presented on Figure 3.

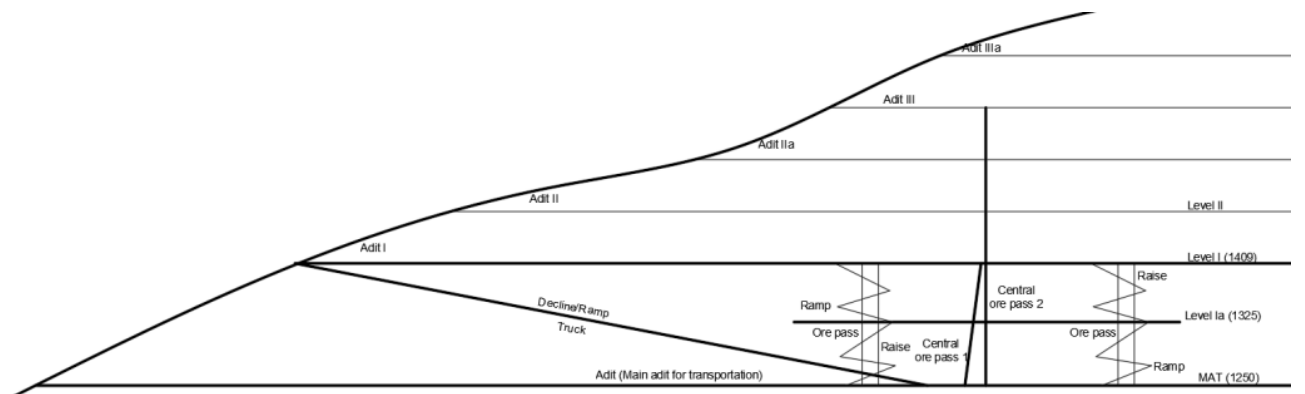

Figure 3 Second variant of opening level I - Ia with the main export decline, while on the level Ia-MAT with existing infrastructure for haulage and ore export

\subsection{Opening with Main haulage decline from surface $(\mathrm{k} .1409 \mathrm{~m})$ to the level of} Main haulage adit (k. 1250m)

In this variant, construction of Main haulage decline from the surface down to the level of the Main haulage adit $(\mathrm{k} .1250 \mathrm{~m})$ is proposed. The ore from the Central ore passes at the MAT level will be haulaged by mine trucks through the Main haulage decline to the surface, and further to the Flotation Bunker. This variant is displayed on Figure 4. 


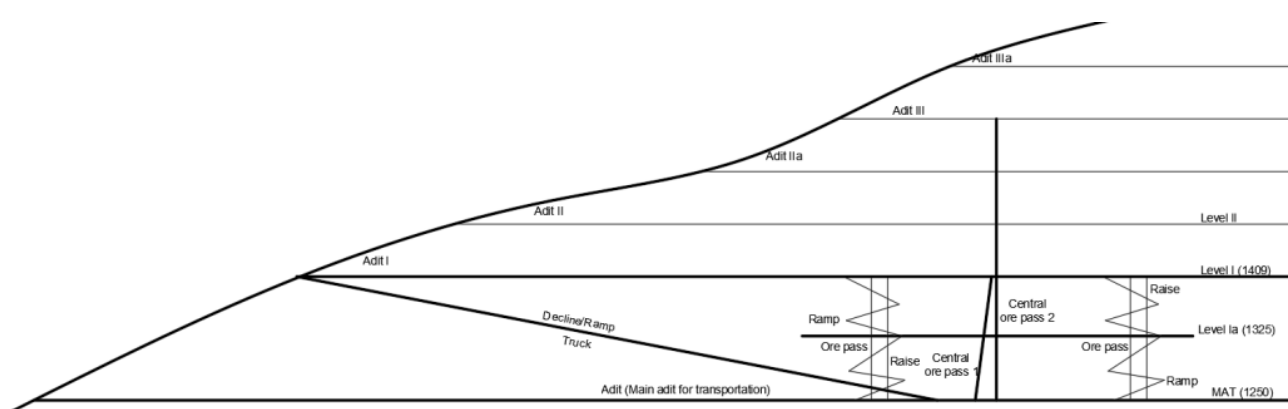

Figure 4 Third variant of opening with construction of main haulage decline from surface to the level of the main haulage adit (k.1250m)

\subsection{Opening with expansion of level I and use of truck haulage}

In this variant, expanded of Adit I is proposed in order to apply truck ore haulage. Namely, with the mine trucks through the Block ramp will come directly to the sublevel, where with diesel loaders the ore will be loaded directly into mine trucks. There is no need to make central ore passes. This variant of opening is presented on Figure 5.

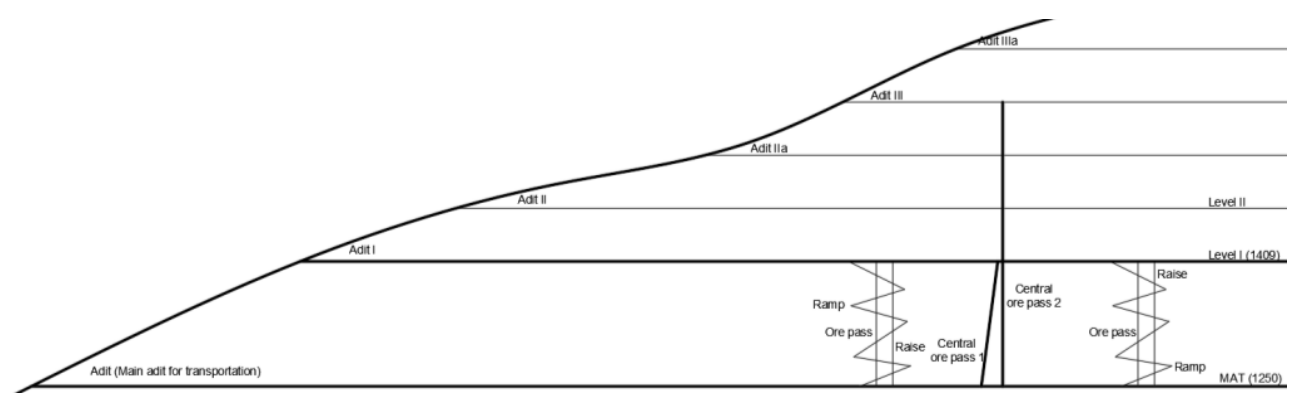

Figure 5 Fourth variant of opening with expansion of Adit I and usage of truck haulage

\subsection{Opening with the construction of a new Adit Ia at an elevation of $1325 \mathrm{~m}$}

In fifth variant, construction of Adit Ia, at elevation $1325 \mathrm{~m}$, is proposed through the ore haulage with mine trucks, as shown on Figure 6 . The central ore pass will be made only to the level Ia ie up to the elevation $1325 \mathrm{~m}$. Namely, the ore produced by level I-Ia in the mine trucks will be loaded from the ore passes, while the ore produced by level IaGIP in the mine trucks will be loaded directly on the sublevel and through the Block ramp and Adit Ia will be haulaged on the surface and further to the receiving flotation bunker. 


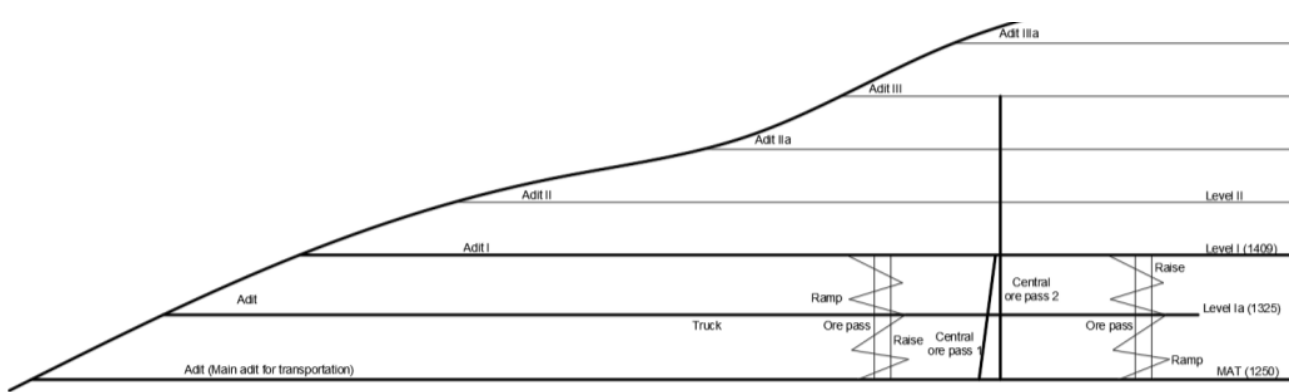

Figure 6 Fifth variant of opening with construction of new adit Ia at an elevation $1325 \mathrm{~m}$

\subsection{Opening with construction of Main haulage decline from surface $(1325 \mathrm{~m})$ to the level of Main haulage adit $(1250 \mathrm{~m})$}

This variant is a sub-variant of variant 3 , because it differs only in terms of the starting point of construction of the Main haulage decline. Construction of Main haulage decline is proposed from surface $(1325 \mathrm{~m})$ to the level of the Main haulage Adit $(1250 \mathrm{~m})$. The ore from the Central ore pass at the MAT level will be haulaged by mine trucks through the Main haulage decline to the surface, and further to the Flotation Bunker. This variant of opening is presented on Figure 7.

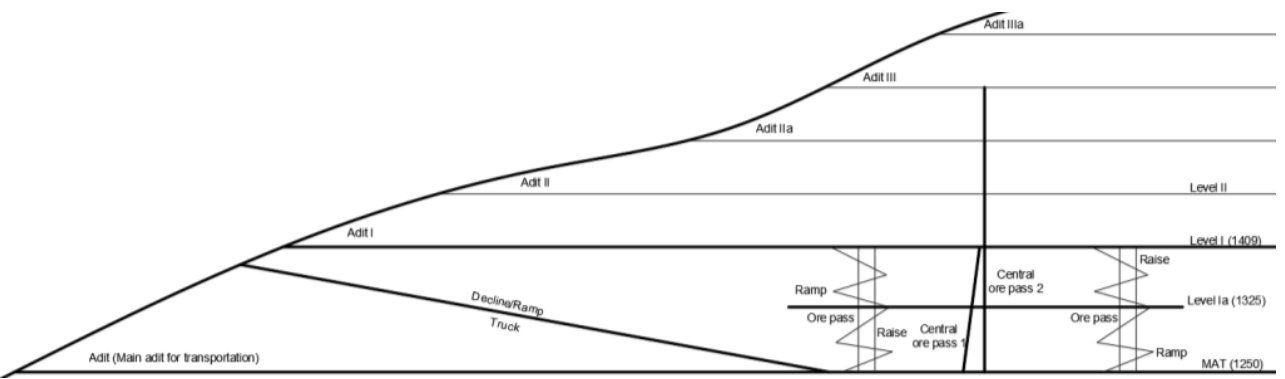

Figure 7 Sixth variant of opening with construction of Main haulage decline from surface (k. $1325 \mathrm{~m}$ ) to the level of Main haulage Adit (k. $1250 \mathrm{~m})$

\section{APPLICATION OF THE METHOD OF INDEXED POINTS FOR SELECTION OF A RATIONAL VARIANT FOR OPENING THE DEEPER PARTS OF TORANICA MINE}

The following text of this paper presents the method of indexed points for rational selection of a variant of opening the ore deposit Toranica under level I.

For all six variants listed previously, the necessary underground facilities have been determined, which will serve as facilities for opening and ore haulage as well as waste rocks haulage and ventilation in the deeper parts of the Toranica mine. Table 1 shown the required new facilities, by types and their length, as well as the length of existing underground facilities that will be in further operation. In table 1a is given the facilities length through which the ore will be haulaged. 
Table 1 Length of required underground facilities for opening and transport

\begin{tabular}{ccccccc}
\hline & \multicolumn{7}{c}{ Length of required facilities [m] } & $\begin{array}{c}\text { Length of existing } \\
\text { facilities to be used } \\
{[\mathbf{m}]}\end{array}$ \\
\hline Variant & Drift & Decline & $\begin{array}{c}\text { Block } \\
\text { ramp }\end{array}$ & $\begin{array}{c}\text { Ore } \\
\text { pass }\end{array}$ & $\begin{array}{c}\text { Expansion - } \\
\text { Drift }\end{array}$ & Drift \\
I & 1682 & & 2600 & 300 & & 2600 \\
II & 2913 & 630 & 2600 & 300 & & 2600 \\
III & 1955 & 1259 & 2600 & 300 & & \\
IV & 1682 & & 2600 & & 1700 & \\
V & 4067 & & 2600 & 150 & & \\
VI & 2462 & 1170 & 2600 & 300 & & \\
\hline
\end{tabular}

Table 1a Length of the facilities through which the ore will be haulaged

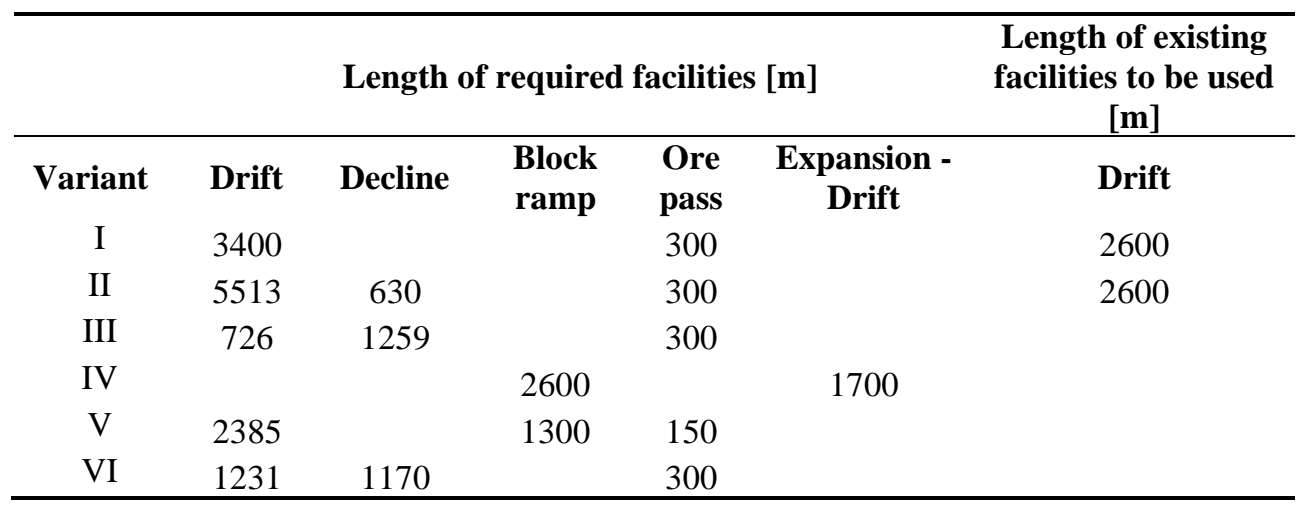

We have already listed construction, maintenance, haulage and ventilation as the most important parameters. Table 2 shown the indexed points, for each of the required facilities, for these parameters.

Table 2 Indexed points for the most important parameters by facility type

\begin{tabular}{lccccc}
\hline $\begin{array}{l}\text { Analyzed } \\
\text { parameters }\end{array}$ & \multicolumn{5}{c}{ Value of index points according to the facility type } \\
& Drift & Decline & $\begin{array}{c}\text { Block } \\
\text { ramp }\end{array}$ & $\begin{array}{c}\text { Ore } \\
\text { pass }\end{array}$ & $\begin{array}{c}\text { Expansion - } \\
\text { Drift }\end{array}$ \\
\hline Construction & 1.5 & 3.0 & 3.5 & 6.0 & 8.0 \\
Maintainer & 1.5 & 2.5 & 3.0 & 2.0 & 2.0 \\
Haulage & 1.0 & 2.5 & 3.0 & 1.5 & 1.0 \\
Ventilation & 1.0 & 1.5 & 2.5 & 1.0 & 1.0 \\
\hline
\end{tabular}

When calculating the coefficients for the costs of construction, maintenance, haulage and ventilation, in all variants, the equation (4) was used, where for annual capacity the predicted capacity $\mathrm{Q}=350000 \mathrm{t}$, and operation period $\mathrm{T}=10$ years is taken. Table 3 
shown the coefficients values for all parameters, for all six variants of opening and haulage, as well as the cumulative value of the coefficients by variants.

Table 3 Coefficients value by variants

\begin{tabular}{lcccccc}
\hline Analyzed parameters & \multicolumn{7}{c}{ Variants for opening and haulage } \\
& I & II & III & IV & V & VI \\
\hline Construction & 3.8 & 4.9 & 5.0 & 6.5 & 4.6 & 5.2 \\
Maintenance & 3.5 & 4.1 & 4.1 & 3.9 & 4.1 & 4.3 \\
Haulage & 1.1 & 2.2 & 1.2 & 2.7 & 1.9 & 1.3 \\
Ventilation & 2.3 & 3.0 & 2.4 & 2.3 & 3.0 & 3.1 \\
Total value & $\mathbf{1 0 . 7}$ & $\mathbf{1 4 . 1}$ & $\mathbf{1 2 . 8}$ & $\mathbf{1 5 . 5}$ & $\mathbf{1 3 . 5}$ & $\mathbf{1 3 . 8}$ \\
\hline
\end{tabular}

Graphically, the total value of the coefficient by variants is shown in Figure 8 . While Figure 9 shown the parameters value of: costs for construction, maintenance, haulage and ventilation for each of the variants.

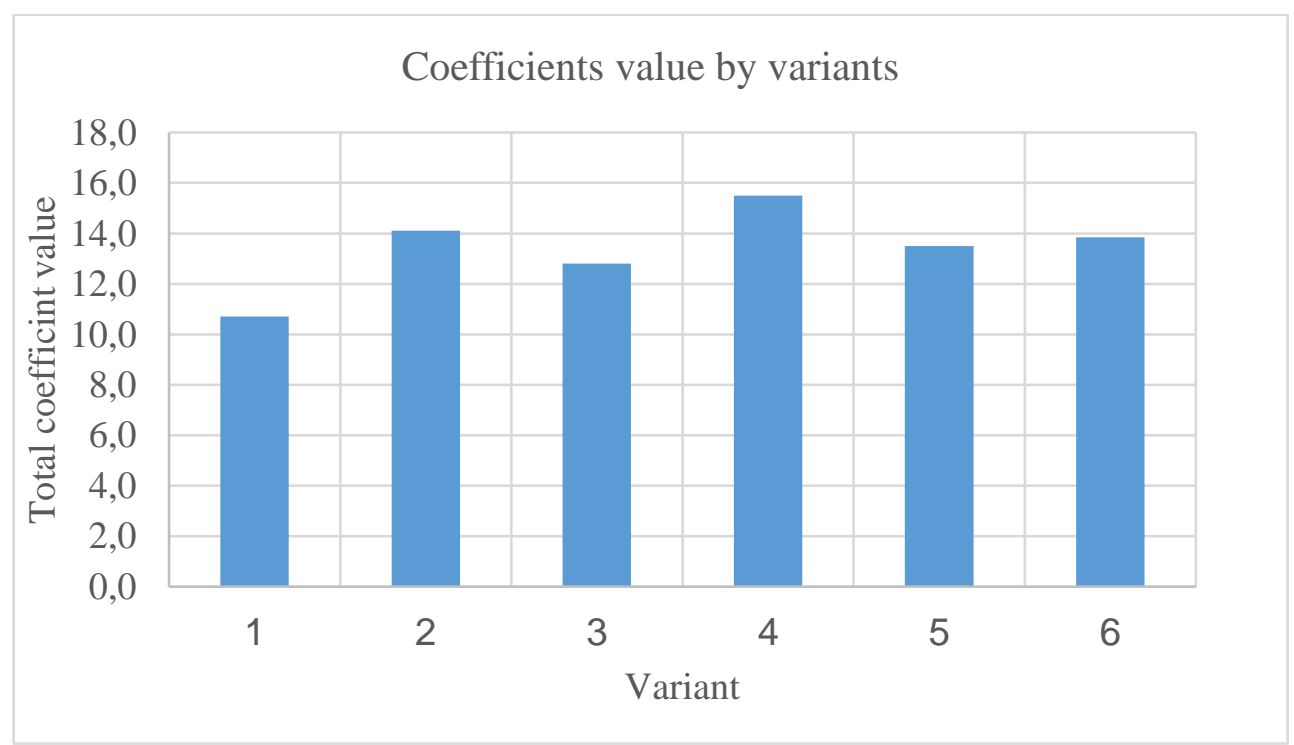

Figure 8 Total coefficient value by variants 


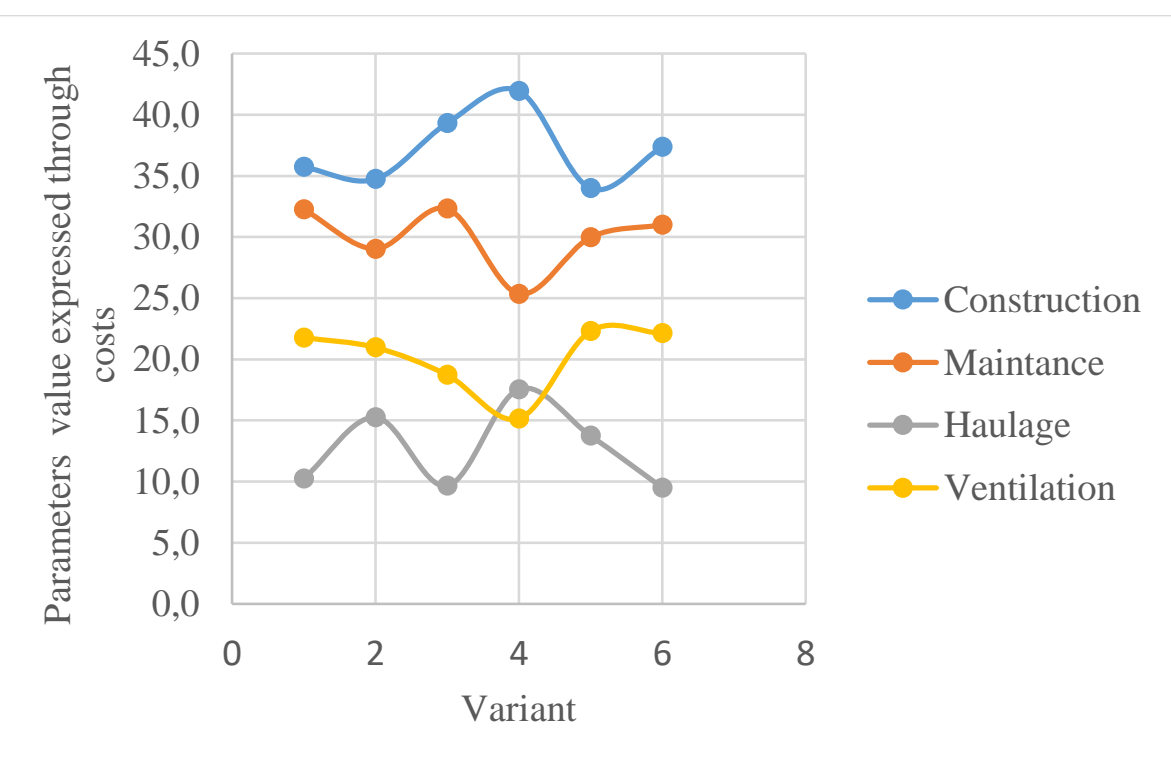

Figure 9 Parameters value expressed through costs for individual operations

Performed analysis shown that the most favorable variant for opening and haulage of the deeper parts of the Toranica mine is the first variant ie the variant using the existing underground infrastructure and railway ore haulage to the receiving Flotation bunker (Table 4).

Table 4 Ranking of opening and haulage variants

\begin{tabular}{cc}
\hline Opening and haulage variants & Rank \\
\hline I & 1 \\
III & 2 \\
V & 3 \\
VI & 4 \\
II & 5 \\
IV & 6 \\
\hline
\end{tabular}

\section{CONCLUSION}

During the preparation of preliminary analyzes and studies for opening of an underground ore deposit, we encounter a lack of information on many input factors in the calculations and analyzes, such as: mining - geological factors, economic factors and organizational factors. On the other hand, the time for a decision making of choosing a rational variant for opening is very short. The methodology with the application of indexed points gives satisfactory results in that regard and can be successfully applied both in processing the problem of opening a new ore deposit and in solving the problem 
of choosing a variant for opening the deeper parts of an existing or active mine as was the example with the Toranica Mine. The methodology is mainly based on the volume, ie length and type of underground facilities that need to be constructed in order to successfully open the underground ore deposit.

\section{REFERENCES}

ДЕСПОДОВ, З., МИЈАЛКОВСКИ, С. (2015) Отворање и разработка на рудни наоѓалишта за подземна експлоатација (скрипта, непублицирана). Штип: Универзитет „Гоце Делчев“

ДОНЕВА, Н. (2016) Принципи во рударството (скрипта, непублицирана). Штип: Универзитет „Гоце Делчев“

GLUŠČEVIĆ, B. (1974) Otvaranje i metode podzemnog otkopavanja rudnih lezista. RGF-Beograd, Subotica-Beograd: Minerva

JOVANOVIĆ, P. (1990) Izrada jamskih prostorija (Knjiga I). Beograd: Rudarskogeoloski fakultet

JOVANOVIĆ, P., TRAJKOVIĆ, S., TOMAŠEVIĆ, A. (1993) Methodical approach of mine opening economical solution defining and export selection method, In: 2-nd International Conference on Mine Hauling and Hoisting. RGF Beograd, pp. 95-100

SAVIĆ, Lj., JANKOVIĆ, R., VIDANOVIĆ, N., LUTOVAC, S. (2011) The character of the of correlation between drilling speed and changes of the observed tehnical parameters in various working environments, In: Technics technologies education menagemen, Vol. 6, No 2, ISSN 1840-1503, Sarajevo 